\title{
Farmer Perceptions of Wildlife Damage to Row Crops in North Florida ${ }^{1}$
}

\author{
Holly K. Ober, Gerald R. Edmondson, William M. Giuliano, David L. Wright, John Atkins, Andy \\ Andreasen, Shep Eubanks, Libbie Johnson, Charles Brasher, and Greg Hicks²
}

Many private landowners encourage wildlife on their property. However, activities of certain species on private lands may create problems. For example, although white-tailed deer are the species Floridians most often want to promote on their lands, deer are also responsible for substantial yield damage to some field crops and ornamental plantings.

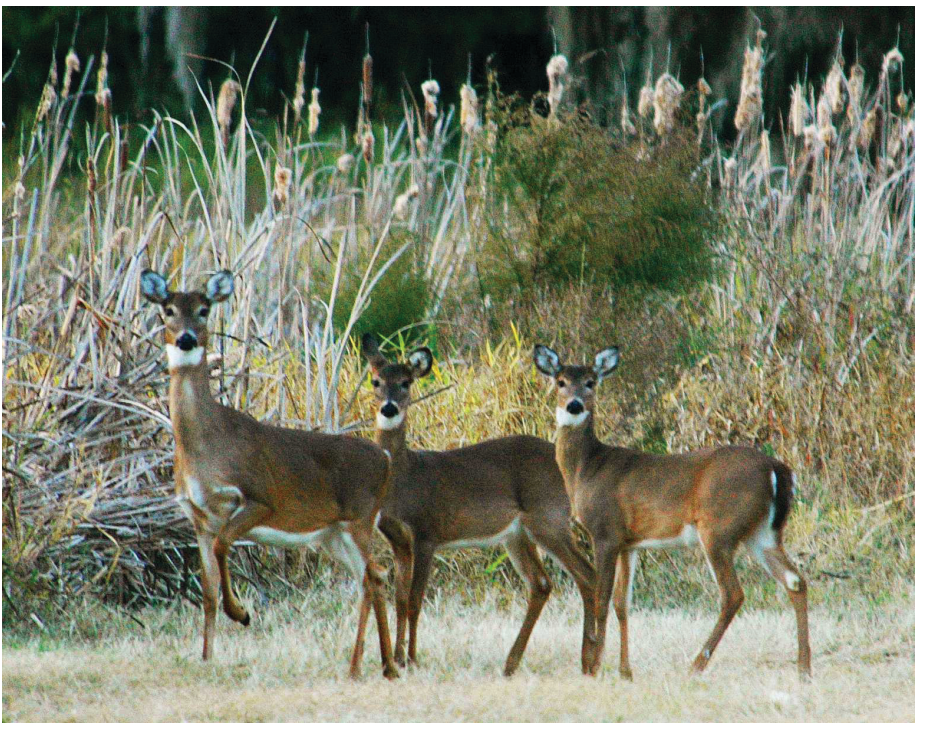

Credits: UF/IFAS
Reports of wildlife damage to agricultural crops have increased over time (Conover and Decker 1991). This damage is not evenly distributed: some growers experience little to no damage while others suffer severe losses. A nationwide survey conducted in the early 1990s found many producers in the Southeast experienced particularly severe economic losses credited to wildlife depredation.

\section{Measuring Crop Depredation}

It is extremely difficult to develop accurate cost estimates associated with wildlife damage to crops. However, approximations of these costs can be useful to illustrate the magnitude of the problems faced by agricultural operators.

Two methods can be used to generate estimates of wildlife damage to crops: direct sampling and indirect sampling. Direct sampling involves on-the-ground surveys of damaged plants in crop fields. This method produces highly accurate results, but it is laborious and therefore expensive, which limits the area that can be surveyed. Indirect sampling relies on self-reporting questionnaires. This type of surveying is cost efficient and can typically cover larger numbers of farms over larger geographic

1. This document is WEC311, one of a series of the Wildlife Ecology and Conservation Department, UF/IFAS Extension. Original publication date July 2011. Revised October 2014. Visit the EDIS website at http://edis.ifas.ufl.edu.

2. Holly K. Ober, extension specialist, Department of Wildlife Ecology and Conservation, University of Florida, North Florida Research and Education Center, Quincy, FL 32351; Gerald R. Edmondson, county extension director, Okaloosa County, Crestview, FL 32536; William M. Giuliano, extension specialist, Department of Wildlife Ecology and Conservation, University of Florida, Gainesville, FL 32605; David L. Wright, extension specialist, Department of Agronomy, University of Florida, North Florida Research and Education Center, Quincy, FL 32351; John Atkins, extension agent, Santa Rosa County, Milton, FL 32570; Andy Andreasen, county extension director, Washington County, Chipley, FL 32428; Shep Eubanks, county extension director, Holmes County, Bonifay, FL 32425; Libbie Johnson, extension Agent, Escambia County, Cantonment, FL 32533, Charles Brasher, extension agent, Jackson County, Marianna, FL 32448; and Greg Hicks, county extension director, Hamilton County, Jasper, FL 32052

The Institute of Food and Agricultural Sciences (IFAS) is an Equal Opportunity Institution authorized to provide research, educational information and other services

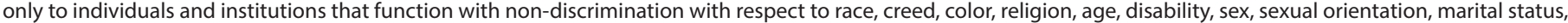
national origin, political opinions or affiliations. For more information on obtaining other UF/IFAS Extension publications, contact your county's UF/IFAS Extension office. U.S. Department of Agriculture, UF/IFAS Extension Service, University of Florida, IFAS, Florida A \& M University Cooperative Extension Program, and Boards of County Commissioners Cooperating. Nick T. Place, dean for UF/IFAS Extension. 
regions. However, these surveys can be biased because of non-random questionnaire distribution, differences in respondents' interpretation of questions, lack of consistency in the identification of species responsible for crop damage, and inaccurate estimation of the number of acres of crops affected. Analysis of this method has shown, however, that while some individual producers may provide inaccurate estimates of crop damage through self-reporting questionnaires, higher producer response rates provided by questionnaires typically lead to a reliable overall damage assessment (Tzilkowski et al. 2002).

A questionnaire was developed to obtain information on crop depredation issues from growers in north Florida. The questions were developed by a team consisting of extension specialists, a county extension director, and a representative from the Florida Farm Bureau. The survey contained 15 questions regarding the types of crops damaged by wildlife during 2009 and 2010, the severity of crop depredation, the species responsible for this damage, and the actions producers took to prevent this crop damage.

Surveys were sent to agricultural extension agents in the 29 counties across north Florida. Agents were asked to distribute the survey to at least 10 randomly selected farms in their counties. Only farmers growing crops commonly damaged by wildlife in the region (corn, cotton, peanuts, peas, soybeans, watermelons, blueberries, and ornamentals), and only farmers working at least 50 acres were solicited for a response.

\section{Characteristics of Farmers Surveyed}

A total of 69 surveys were returned, with respondents from nine counties across north Florida (Escambia, Santa Rosa, Okaloosa, Holmes, Washington, Gulf, Jackson, Gadsden, and Hamilton).

These individuals owned or leased 53,245 acres, collectively. The median acreage per farmer was 450 acres, with a median field size of 30 acres. The crops grown most commonly were peanuts ( $80 \%$ of respondents), corn (65\%), cotton (54\%), soybeans (54\%), peas (48\%), and watermelons (36\%). All respondents reported having at least one type of crop damaged by wildlife during the past two years. When asked whether the amount of wildlife damage to crops had changed over the past five years, the overwhelming majority of respondents $(86 \%)$ indicated the amount of damage had increased.

\section{Wildlife Responsible for Crop Damage}

Farmers reported that a variety of wildlife species were responsible for the crop damage they experienced during the past two years. The majority of crop damage was attributed to these species:

- white-tailed deer (damage reported by $94 \%$ of farmers)

- wild hogs (61\%)

- coyotes $(33 \%)$

- raccoons $(30 \%)$

- $\operatorname{armadillos}(19 \%)$

- rabbits (10\%)

A small number of respondents reported crop damage from bears, squirrels, foxes, crows, turkeys, opossums, moles, and rats ( $<5 \%$ of respondents for each of these animals).

The evidence farmers used to determine which species were responsible for damage included: visual observations of the animals in or near crop fields (80\%), observations of tracks or scat (56\%), observation of damage to plants (43\%), and digging or rooting in crop fields (25\%).

It was not surprising that deer were the primary source of crop depredation reported. Many previous nationwide and regional surveys have shown similar patterns, with deer responsible for the majority of damage to crops.

\section{Types of Crops Damaged by Deer and Hogs}

Cotton and peanuts experienced the most extensive damage from white-tailed deer and feral hogs when considering number of acres affected. This was to be expected, given the large acreages over which these two crops are grown in north Florida. When considering the percentage of each crop damaged, watermelons and soybeans suffered most extensively from deer, while watermelons and corn suffered most extensively from hogs (Table 1).

Damage was not distributed evenly among producers. Statistics showed regional patterns: in general, deer damage was highest among farms in the western Panhandle region (Escambia, Santa Rosa, and Okaloosa counties), whereas hog damage was highest among farms in the central Panhandle region (Holmes, Washington, Jackson, and Gulf counties). 
When considering only those producers who reported damage to each crop, average losses exceeded 50\% during both 2009 and 2010 for corn, peas, soybeans, and watermelons, indicating that most producers who experienced damage to these crops faced severe depredation pressure.

\section{Monetary Losses Caused by Wildlife}

Respondents reported a loss of 3,888 acres of crops because of deer and wild hogs in 2009 and 3,726 acres in 2010. To develop standardized estimates of economic losses resulting from deer and hog damage to each of the major crops in north Florida, we used the following formula:

Monetary loss $=$ acres planted $x$ crop yield $x$ price received $x$ $\%$ acres damaged

Acreage planted and yields used in calculations were those reported from U.S. Department of Agriculture National Agricultural Statistics Service (USDA NASS) reports for 2009 for District 10. This district spans from Escambia County to Jefferson County, encompassing 8 of the 9 counties from which we collected data. Prices were those reported by NASS for the entire state of Florida for 2009. See tables 2 and 3 for estimates of financial losses from deer and wild hogs.

Deer and wild hogs were responsible for similar economic losses to corn, while deer were responsible for a far greater proportion of economic losses than wild hogs for soybeans, cotton, and peanut crops. Overall, economic losses from deer were more than four times those from hogs.

The high percentage of acreage of some crops lost to deer suggests a need for changes in deer management in the region. Many producers can absorb small crop losses, but large losses make it challenging for them to sustain profitability. It should be noted that loss estimates reported here under-report total net losses because they do not account for the expenditures associated with replanting or with wildlife control practices.

\section{Wildlife Damage Management Efforts}

Survey respondents employed many techniques to reduce crop damage, with hunting the most commonly used method. The damage control techniques reported included the following:
- shooting (harvesting animals through hunting and through depredation permits; reported by $78 \%$ of farmers)

- chemical repellents (36\%)

- flagging (34\%)

- fencing $(30 \%)$

- frightening devices (25\%)

- trapping (5\%)

During the previous two years, farmers reported removing an average of 13 deer per farmer per year through depredation permits, 11 deer per farmer per year through hunting, and 8 hogs per farmer per year through hunting or trapping. (Depredation permits provide permission for private landowners to harvest animals causing damage to crops outside regular hunting seasons.)

Interestingly, the number of deer depredation permits issued by the Florida Fish and Wildlife Conservation Commission has also increased in recent years in north Florida. This indicates the increased intention of farmers to control deer populations in the region. The rising number of depredation permits also suggests farmers are devoting more resources, including labor, towards deer damage control. Labor costs should not be overlooked when assessing crop damage caused by wildlife in north Florida.

\section{Implications}

Wildlife provides a variety of benefits for private landowners. Many landowners are willing to spend time and money to enhance habitat for wildlife on their property, with deer often the primary focus of these efforts. Because deer are valued economically and recreationally by many hunters, some private landowners are tolerant of a certain degree of damage from this species. However, the survey results indicate that damage levels caused by deer to agronomic crops (i.e., cotton, peanuts, soybeans, and watermelons) may have surpassed the threshold of tolerance of some agricultural producers in north Florida.

\section{Sources of Additional Information}

Conover, M. R., and D. J. Decker. 1991. Wildlife damage to crops: perceptions of agricultural and wildlife professionals in 1957 and 1987. Wildlife Society Bulletin 19: 46-52.

Florida Fish and Wildlife Conservation Commission. Nuisance Wildlife Permits. Available at http://myfwc.com/ license/wildlife/nuisance-wildlife\#deer 
Iowa Department of Natural Resources. Identifying crop damage. Available at http://www.iowadnr.gov/ portals/idnr/uploads/Hunting/depredation_whodunnit1. pdf?amp;tabid=1225 [October 2011].

Ober, H. K., M. B. Main, and J. Schaefer. Coping with deer damage in Florida. University of Florida/IFAS Extension document WEC 135. http://edis.ifas.ufl.edu/pdffiles/uw/ uw12800.pdf

Sanders, S., C. Wynn, A. S. Wilcox, and W. M. Giuliano. 2009. Private landowners and wildlife in Florida. Available at http://myfwc.com/media/122365/LAP_Booklet.pdf

Tzilkowski, W. M., M. C. Brittingham, and M. J. Lovallo. 2002. Wildlife damage to corn in Pennsylvania: farmer and on-the-ground estimates. Journal of Wildlife Management 66: 678-682. 
Table 1. Total number of acres of each of the major crops damaged and percentage of acres of each crop damaged due to whitetailed deer and wild hogs during 2009 and 2010, as reported in surveys.

\begin{tabular}{|c|c|c|c|c|c|}
\hline \multirow[b]{2}{*}{ Crop } & \multirow{2}{*}{$\begin{array}{c}\text { Total \# of } \\
\text { acres grown }\end{array}$} & \multicolumn{2}{|c|}{ Acreage damaged by deer } & \multicolumn{2}{|c|}{ Acreage damaged by hogs } \\
\hline & & $\#$ of acres & $\%$ of acres grown & \#of acres & $\%$ of acres grown \\
\hline Corn & 8,649 & 266 & 3.1 & 266 & 3.1 \\
\hline Cotton & 37,100 & 2347 & 6.3 & 322 & 0.9 \\
\hline Peanuts & 30,148 & 2081 & 6.9 & 862 & 2.9 \\
\hline Peas & 4,475 & 254 & 5.7 & 7 & 0.2 \\
\hline Soybeans & 9,663 & 929 & 9.6 & 35 & 0.4 \\
\hline Watermelons & 398 & 111 & 27.9 & 14 & 3.5 \\
\hline
\end{tabular}

Table 2. Cost estimates for damage to each of the major crops from white-tailed deer during 2009 in north Florida.

\begin{tabular}{|c|c|c|c|c|c|}
\hline Crop & Acres planted* & Yield** & Price*** & $\%$ acreage lost $* * * *$ & Estimated value of losses \\
\hline Corn & 26,400 & 114 & $\$ 4.00$ & 3.2 & $\$ 382,582$ \\
\hline Cotton & 82,000 & 723 & $\$ 0.66$ & 7.2 & $\$ 2,820,075$ \\
\hline Peanuts & 69,700 & 3,120 & $\$ 0.21$ & 7.6 & $\$ 3,432,034$ \\
\hline Soybeans & 37,000 & 38 & $\$ 9.50$ & 10.9 & $\$ 1,458,959$ \\
\hline \multicolumn{5}{|l|}{ Total } & $\$ 8,093,650$ \\
\hline \multicolumn{6}{|c|}{$\begin{array}{l}\text { *Acres planted reported by NASS for District } 10 \text { in } 2009 \\
\text { **Yield reported by NASS for District } 10 \text { in } 2009 \text { (in lb/acre or bushel/acre) } \\
\text { ***Price reported by NASS for state of FL in } 2009 \text { (in } \$ / / \mathrm{lb} \text { or } \$ / \text { bushel) } \\
\text {***\% acreage lost as self-reported in surveys for } 2009\end{array}$} \\
\hline
\end{tabular}

Table 3. Cost estimates for damage to each of the major crops from wild hogs during 2009 in north Florida.

\begin{tabular}{|c|c|c|c|c|c|}
\hline Crop & Acres planted* & Yield** & Price ${ }^{* * *}$ & $\%$ acreage lost $* * * *$ & Estimated value of losses \\
\hline Corn & 26,400 & 114 & $\$ 4.00$ & 2.6 & $\$ 314,739$ \\
\hline Cotton & 82,000 & 723 & $\$ 0.66$ & 0.8 & $\$ 327,943$ \\
\hline Peanuts & 69,700 & 3,120 & $\$ 0.21$ & 2.6 & $\$ 1,151,178$ \\
\hline Soybeans & 37,000 & 38 & $\$ 9.50$ & 0.2 & $\$ 30,815$ \\
\hline \multicolumn{5}{|l|}{ Total } & $\$ 1,824,675$ \\
\hline \multicolumn{6}{|c|}{$\begin{array}{l}\text { *Acres planted reported by NASS for District } 10 \text { in } 2009 \\
\text { **Yield reported by NASS for District } 10 \text { in } 2009 \text { (in lb/acre or bushel/acre) } \\
\text { ***Price reported by NASS for state of FL in } 2009 \text { (in } \$ / \text { lb or } \$ / \text { bushel) } \\
\text { ***\%acreage lost as self-reported in surveys for } 2009\end{array}$} \\
\hline
\end{tabular}

